\title{
A Review of Electrospun Carbon Nanofiber-Based Negative Electrode Materials for Supercapacitors
}

\author{
Arjun Prasad Tiwari ${ }^{1, *,+} \mathbb{D}$, Tanka Mukhiya ${ }^{2,3,+}{ }^{,}$Alagan Muthurasu ${ }^{3}$, Kisan Chhetri $^{3}$, Minju Lee $^{3}$, \\ Bipeen Dahal ${ }^{3,4}$, Prakash Chandra Lohani ${ }^{3}$ and Hak-Yong Kim ${ }^{3, *(D)}$ \\ 1 Carbon Nano Convergence Technology for Next generation Engineers (CNN), Jeonju 561-756, Korea \\ 2 Department of Chemistry, Bhaktapur Multiple Campus, Tribhuvan University, Kirtipur 44618, Nepal; \\ tankamukhiya@yahoo.com \\ 3 Department of Nano Convergence Engineering, Jeonbuk National University, Jeonju 561-756, Korea; \\ amuthurasu@gmail.com (A.M.); kisanchhetri604@gmail.com (K.C.); minju_4@naver.com (M.L.); \\ dahalbipeen@gmail.com (B.D.); sansi4546@gmail.com (P.C.L.) \\ 4 Central Department of Chemistry, Tribhuvan University, Kirtipur 44618, Nepal \\ * Correspondence: tiwariarjuna@jbnu.ac.kr (A.P.T.); dragon4875@gmail.com (H.-Y.K.) \\ + These authors contributed equally.
}

check for

updates

Citation: Tiwari, A.P.; Mukhiya, T.; Muthurasu, A.; Chhetri, K.; Lee, M.; Dahal, B.; Lohani, P.C.; Kim, H.-Y. A Review of Electrospun Carbon

Nanofiber-Based Negative Electrode Materials for Supercapacitors.

Electrochem 2021, 2, 236-250.

https://doi.org/10.3390/

electrochem 2020017

Academic Editor: Masato Sone

Received: 7 April 2021

Accepted: 10 May 2021

Published: 13 May 2021

Publisher's Note: MDPI stays neutral with regard to jurisdictional claims in published maps and institutional affiliations.

Copyright: (c) 2021 by the authors. Licensee MDPI, Basel, Switzerland. This article is an open access article distributed under the terms and conditions of the Creative Commons Attribution (CC BY) license (https:/ / creativecommons.org/licenses/by/ $4.0 /)$.

\begin{abstract}
The development of smart negative electrode materials with high capacitance for the uses in supercapacitors remains challenging. Although several types of electrode materials with high capacitance in energy storage have been reported, carbon-based materials are the most reliable electrodes due to their high conductivity, high power density, and excellent stability. The most common complaint about general carbon materials is that these electrode materials can hardly ever be used as free-standing electrodes. Free-standing carbon-based electrodes are in high demand and are a passionate topic of energy storage research. Electrospun nanofibers are a potential candidate to fill this gap. However, the as-spun carbon nanofibers (ECNFs) have low capacitance and low energy density on their own. To overcome the limitations of pure CNFs, increasing surface area, heteroatom doping and metal doping have been chosen. In this review, we introduce the negative electrode materials that have been developed so far. Moreover, this review focuses on the advances of electrospun nanofiber-based negative electrode materials and their limitations. We put forth a future perspective on how these limitations can be overcome to meet the demands of next-generation smart devices.
\end{abstract}

Keywords: electrospinning; negative electrode materials; carbon nanofibers; free-standing; supercapacitor

\section{Introduction}

Electrical energy has been an indispensable aspect of human civilization. It is essential for day-to-day activities, developing infrastructures, discovering new technologies, and driving the economy. Currently, fossil fuels are the primary energy sources, contributing more than two-thirds of total electricity generation; however, global energy demand continues to increase [1-3]. Additionally, fossil fuels are the main contributor of $\mathrm{CO}_{2}$ emissions that are responsible for life-threatening global warming. Moreover, fossil fuel sources are being rapidly exhausted and they are inherently non-renewable [4]. The above facts demonstrate the urgent need for renewable, clean, and sustainable energy sources, and research has moved in this direction. However, energy generated from renewable sources such as hydro, solar, and wind is intermittent, and there is a large fluctuation in energy output. Therefore, energy generated from these sources has to be stored so it can be supplied when and where it is needed. The development of efficient electrical energy storage technology that can store a large amount of energy from intermittent and fluctuating renewable sources has been one of the major obstacles to a fossil fuel-free, clean, and sustainable society [5]. Currently, batteries and supercapacitors (SCs) are two major 
energy storage technologies. Li-ion batteries, with their high energy density ( $\sim 300 \mathrm{~W} \mathrm{~h}$ $\mathrm{kg}^{-1}$ ), have tremendously contributed to this field and were recognized with the Nobel prize in Chemistry 2019; however, batteries suffer from a limited operating life (a few thousand cycles), slow recharge rate, low power density, and safety issues [6,7]. SCs, due to their attractive features, such as their fast charge and discharge rates (s to min), high power density $\left(\sim 10^{5} \mathrm{~W} \mathrm{~kg}^{-1}\right)$, and long operating life ( $>10^{6}$ charge-discharge cycles), are a promising alternative or complement to batteries [8,9]. Moreover, SCs are better than batteries in regard to safety. Commercialized for the first time under the name "supercapacitor", SCs, are currently available for various applications. However, the widespread stand-alone utility of SCs has been limited mainly due to the low energy storage capacity per unit mass, volume, or area of their electrodes. Therefore, the current research approach is to increase the energy storing capacity of SCs without compromising their cycling life and power density mainly by developing efficient electrode materials [10]. Over the past decades, nanoscale carbon materials, conducting polymers, transition metal compounds, and their composites have been explored as electrode materials and have shown promising results. A large specific surface area, high electronic conductivity, and abundance of active sites are the primary requirements of active electrode materials. Additionally, high porosities and proper nanoarchitectures are other promising features [11-13]. Finally, being lightweight and flexible are additional requirements for portable, flexible, and wearable devices. Apart from these factors, the use of cost-effective and ecofriendly materials, availability of simple and fast fabrication processes, demonstration of multifunctional use, and capacity for mass production are parameters that are always at the center of commercial materials.

\section{Negative Electrode Materials}

Basically, a supercapacitor consists of two electrodes, namely, a positive electrode and a negative electrode that are separated by an electrolyte-rich semipermeable membrane identified as the separator. When comparing the energy density of an energy storage device, there is a very large gap between a battery and a supercapacitor device. A battery has a high energy density but a low power density, while a supercapacitor has exactly the opposite. Herein, obtaining a supercapacitor device with a high energy density is the main challenge, and this needs to be significantly improved to meet the increasing energy density demands of next-generation high-tech devices. It is well known that the energy density of a device depends on the working potential window of the device and the capacitance, as indicated by the formula, Energy density $(E)=1 / 2 \mathrm{CV}^{2}$, where $C$ is the capacitance and $V$ is the working potential window. This demand further focuses on developing devices with a high capacitance that work over a wide potential range. Several thousands of studies have focused on the development of pseudocapacitor electrode materials with high capacitance. Pseudocapacitance is the combination of a capacitor-type material and a redox material. Generally, research on novel materials for supercapacitor applications is extremely active but is mostly done for positive electrode materials (cathodes). Wu et al. fabricated nickel-cobalt layered double hydroxide as a cathode material, which exhibited $2682 \mathrm{~F} \mathrm{~g}^{-1}$ at a current density of $3 \mathrm{~A} \mathrm{~g}^{-1}$ [14]. In another work, Liang et al. [15] fabricated an oxygen vacancy-rich nickel-cobalt layered double hydroxide electrode that demonstrated $1563 \mathrm{~F} \mathrm{~g}^{-1}$ capacitance at a current density of $1 \mathrm{~A} \mathrm{~g}^{-1}$. However, the common properties of metal-based positive electrode materials are that they work within small potential ranges $(0-0.5 / 6 \mathrm{~V})$ [14-17]. This result means that the assembly of a supercapacitor device by using only the above materials cannot lead to a high enough energy density. On the other hand, carbon-based materials have been used as anodes that work over a wide range of negative potentials while demonstrating lower capacitance values than cathode materials. The assembly of a positive electrode material with carbon-based materials as the asymmetric supercapacitor device significantly improves the energy density of the device due to the synergistic effect of both types of electrode materials. Hence, the development of anode materials that have relatively high capacitance but work over a wide potential window is imperatively important. In this regard, several attempts have been made to 
obtain anode materials with desirable properties. The major negative electrode materials include tin-based [18,19], copper-based [20], vanadium-based [21,22], MO-based [23,24], iron-based [25-27], and carbon-based electrode materials [28-32] (Table 1). We review the carbon fiber-based negative electrode details in this report.

Compared to carbon-based materials, metal-based negative electrode materials have been reported to show superior capacitance values. The major concerns of metal-based materials are the phase changes that occur due to the redox activity during long-term use and their low conductivity, notably limiting their uses [33-35]. Thus far, only carbon materials have been used in commercial electrical supercapacitor devices due to their excellent stability under various conditions, such as $\mathrm{pH}$ and temperature. Moreover, carbon materials have desirable properties, such as a large surface area and outstanding conductivity, compared to metal-based electrodes. The major carbon materials are activated carbon (AC) [36,37], carbon nanotubes (CNTs) [38,39], graphene [40], carbon cloth (CC) [41], electrospun carbon nanofibers [32,42,43], porous carbons [44-46], and their composites (Table 1).

Table 1. List of negative electrode materials reported in the literature.

\begin{tabular}{|c|c|c|c|c|c|}
\hline S.N. & Electrode Materials & Electrolyte & Capacitance & Current density & Reference \\
\hline 1. & Iron phosphide $(\mathrm{FeP})$ nanotubes & $1 \mathrm{M} \mathrm{LiCl}$ & $149.11 \mathrm{~F} \mathrm{~g}^{-1}$ & $1 \mathrm{~mA} \mathrm{~cm}^{-2}$ & [27] \\
\hline 2. & Activated CNF & $6 \mathrm{M} \mathrm{KOH}$ & $156.0 \mathrm{~F} \mathrm{~g}^{-1}$ & $0.5 \mathrm{~A} \mathrm{~g}^{-1}$ & [31] \\
\hline 3. & Carbon-coated tin nitride (TiN) & $1 \mathrm{M} \mathrm{KOH}$ & $167.0 \mathrm{~F} \mathrm{~g}^{-1}$ & $1 \mathrm{Ag}^{-1}$ & [19] \\
\hline 4. & $\begin{array}{c}\text { 80:20 PAN, } \\
\text { Poly(acrylonitrile-co-butadiene } \\
\text { (PAN/PAN-co-PB) derived CNF }\end{array}$ & $2 \mathrm{M} \mathrm{KOH}$ & $172.0 \mathrm{~F} \mathrm{~g}^{-1}$ & $1 \mathrm{Ag}^{-1}$ & [29] \\
\hline 5. & $\mathrm{CNF} /$ graphene & $6 \mathrm{M} \mathrm{KOH}$ & $183.0 \mathrm{~F} \mathrm{~g}^{-1}$ & $1 \mathrm{Ag}^{-1}$ & [47] \\
\hline 6 & $\begin{array}{l}\text { ZIF-8 derived nanoporous carbon } \\
\text { (ZIF-8/NPC) }\end{array}$ & $3 \mathrm{M}(\mathrm{KOH})$ & $190.0 \mathrm{~F} \mathrm{~g}^{-1}$ & $1 \mathrm{Ag}^{-1}$ & {$[45,48]$} \\
\hline 7. & $\begin{array}{l}\text { Nitrogen-doped hollow activated } \\
\text { carbon nanofibers (HACNFs) }\end{array}$ & $6 \mathrm{M} \mathrm{KOH}$ & $197.0 \mathrm{~F} \mathrm{~g}^{-1}$ & $0.2 \mathrm{~A} \mathrm{~g}^{-1}$ & [49] \\
\hline 8. & $\begin{array}{l}\text { Nitrogen doped NCFs@polypyrrole } \\
\text { (NCNF-900@PPy) }\end{array}$ & $6 \mathrm{M} \mathrm{KOH}$ & $202.0 \mathrm{~F} \mathrm{~g}^{-1}$ & $1 \mathrm{Ag}^{-1}$ & [50] \\
\hline 9. & $\begin{array}{l}\text { Three-dimensional porous CNFs } \\
\text { (P@3D-CNF) }\end{array}$ & $2 \mathrm{M} \mathrm{KOH}$ & $205.5 \mathrm{~F} \mathrm{~g}^{-1}$ & $1 \mathrm{Ag}^{-1}$ & [28] \\
\hline 10. & $\begin{array}{l}\text { ZIF-7/glucose composite-derived } \\
\text { carbon-L-950 }\end{array}$ & $6 \mathrm{M} \mathrm{KOH}$ & $228.0 \mathrm{~F} \mathrm{~g}^{-1}$ & $0.1 \mathrm{Ag}^{-1}$ & [46] \\
\hline 11. & $\begin{array}{l}\text { Graphene/carbon nanotube/iron } \\
\text { oxide }\left(\mathrm{G} / \mathrm{CNT} / \mathrm{Fe}_{2} \mathrm{O}_{3}-150\right)\end{array}$ & $1 \mathrm{M} \mathrm{Li}_{2} \mathrm{SO}_{4}$ & $258.0 \mathrm{~F} \mathrm{~g}^{-1}$ & $1 \mathrm{Ag}^{-1}$ & [51] \\
\hline 12. & $\begin{array}{c}\text { CNF-40 (Polystyrene foam/PAN, } \\
\text { PF:PAN = 40:60) }\end{array}$ & $1 \mathrm{M} \mathrm{H}_{2} \mathrm{SO}_{4}$ & $271.6 \mathrm{~F} \mathrm{~g}^{-1}$ & $0.5 \mathrm{Ag}^{-1}$ & [52] \\
\hline 13. & $\begin{array}{c}\text { Vanadium pentoxide } \mathrm{V}_{2} \mathrm{O}_{5} / \text { vertically } \\
\text { aligned CNTs composites } \\
\left(\mathrm{V}_{2} \mathrm{O}_{5} / \mathrm{VACNT}\right)\end{array}$ & $\begin{array}{l}1 \mathrm{M} \text { sodium sulphate } \\
\qquad\left(\mathrm{Na}_{2} \mathrm{SO}_{4}\right)\end{array}$ & $284.0 \mathrm{~F} \mathrm{~g}^{-1}$ & $2 \mathrm{Ag}^{-1}$ & [21] \\
\hline 14 & $\begin{array}{l}\text { Three dimensional boron-doped CNF } \\
\text { (3D-BN-CNF-F900) }\end{array}$ & $2 \mathrm{M} \mathrm{KOH}$ & $295.0 \mathrm{~F} \mathrm{~g}^{-1}$ & $0.5 \mathrm{~A} \mathrm{~g}^{-1}$ & [42] \\
\hline 15. & Porous CNF-3 & $6 \mathrm{M} \mathrm{KOH}$ & $314.0 \mathrm{~F} \mathrm{~g}^{-1}$ & $0.5 \mathrm{~A} \mathrm{~g}^{-1}$ & [53] \\
\hline 16. & $\begin{array}{l}\text { Reduced graphene oxide-CNF } \\
\text { (rGO-CNF, 1:1) }\end{array}$ & $6 \mathrm{M} \mathrm{KOH}$ & $316.5 \mathrm{~F} \mathrm{~g}^{-1}$ & $0.25 \mathrm{~A} \mathrm{~g}^{-1}$ & [43] \\
\hline
\end{tabular}


Table 1. Cont.

\begin{tabular}{|c|c|c|c|c|c|}
\hline S.N. & Electrode Materials & Electrolyte & Capacitance & Current density & Reference \\
\hline 17. & $\begin{array}{l}\text { PAN: poly(m-aminophenol } \\
\text { (PmAP)-NCNF }\end{array}$ & $6 \mathrm{M} \mathrm{KOH}$ & $347.5 \mathrm{~F} \mathrm{~g}^{-1}$ & $0.5 \mathrm{~mA} \mathrm{~cm}^{-2}$ & [54] \\
\hline 18. & Porous CNFs & $6 \mathrm{M} \mathrm{KOH}$ & $362.0 \mathrm{~F} \mathrm{~g}^{-1}$ & $0.2 \mathrm{~A} \mathrm{~g}^{-1}$ & [55] \\
\hline 19. & $\begin{array}{l}\text { hierarchical porous carbon nanotube } \\
\text { (HPCT) }\end{array}$ & $6 \mathrm{M} \mathrm{KOH}$ & $386.2 \mathrm{~F} \mathrm{~g}^{-1}$ & $0.1 \mathrm{~A} \mathrm{~g}^{-1}$ & [56] \\
\hline 20. & CNT@Graphene & $6 \mathrm{M} \mathrm{KOH}$ & $401.0 \mathrm{~F} \mathrm{~g}^{-1}$ & $1 \mathrm{Ag}^{-1}$ & [30] \\
\hline 21. & $\begin{array}{l}\text { Molybdenum oxide/sulphide } \\
\left(\mathrm{MoO}_{2} / \mathrm{MoS}_{2}\right)\end{array}$ & $1 \mathrm{M} \mathrm{Na}_{2} \mathrm{SO}_{4}$ & $433.3 \mathrm{~F} \mathrm{~g}^{-1}$ & $5 \mathrm{mV} \mathrm{s}^{-1}$ & [23] \\
\hline 22. & CNT@CNF & $6 \mathrm{M} \mathrm{KOH}$ & $464.2 \mathrm{~F} \mathrm{~g}^{-1}$ & $0.5 \mathrm{~A} \mathrm{~g}^{-1}$ & [57] \\
\hline 23. & $\begin{array}{l}\text { Electrodeposited molybdenum oxide } \\
\text { (MoOx) film }\end{array}$ & $1 \mathrm{M} \mathrm{H}_{2} \mathrm{SO}_{4}$ & $507.0 \mathrm{~F} \mathrm{~g}^{-1}$ & $1 \mathrm{Ag} \mathrm{g}^{-1}$ & [24] \\
\hline 24. & $\begin{array}{l}\text { Carbon nanotube@graphene-CNFs } \\
\text { (CNT@Gr-CNF-5) }\end{array}$ & $6 \mathrm{M} \mathrm{KOH}$ & $521.5 \mathrm{~F} \mathrm{~g}^{-1}$ & $0.25 \mathrm{~A} \mathrm{~g}^{-1}$ & [39] \\
\hline 25. & $\begin{array}{c}\text { Amorphous cobalt } \\
\text { phosphate/porous carbon on CC } \\
\text { (a-PC@CoPi-CC })\end{array}$ & $2 \mathrm{M} \mathrm{KOH}$ & $\begin{array}{c}606.1 \mathrm{~F} \mathrm{~g} \mathrm{~g}^{-1} \\
\left(2.15 \mathrm{~F} \mathrm{~cm}^{-2}\right)\end{array}$ & $\begin{array}{c}1 \mathrm{~A} \mathrm{~g}^{-1} \\
\left(4 \mathrm{~mA} \mathrm{~cm}^{-2}\right)\end{array}$ & [58] \\
\hline 26. & $\begin{array}{l}\text { Tantalum in copper sulphide } \\
\left(\mathrm{Ta}-\mathrm{Cu}_{7} \mathrm{~S}_{4}\right)\end{array}$ & $1 \mathrm{M} \mathrm{KOH}$ & $675.0 \mathrm{~F} \mathrm{~g}^{-1}$ & $1 \mathrm{Ag}^{-1}$ & {$[20]$} \\
\hline 27. & 3D Titanium Carbide $\left(\mathrm{Ti}_{3} \mathrm{C}_{2}\right)$ aerogel & $1 \mathrm{M} \mathrm{KOH}$ & $1012.0 \mathrm{mF} \mathrm{cm}^{-2}$ & $2 \mathrm{mV} \mathrm{s}^{-1}$ & [18] \\
\hline 28. & Vanadium oxides (VOx) & $\begin{array}{l}5 \mathrm{M} \text { lithium chloride } \\
\qquad(\mathrm{LiCl})\end{array}$ & $\begin{array}{l}1.57 \mathrm{~F} \mathrm{~cm}^{-2} \\
1652.3 \mathrm{~F} \mathrm{~g}^{-1}\end{array}$ & $2 \mathrm{~mA} \mathrm{~cm}^{-2}$ & [22] \\
\hline
\end{tabular}

\section{Carbon-Based Negative Electrode Materials}

The conventional electrode material for electrical double-layer capacitors (EDLCs) is porous AC with a large specific surface area of $\sim 2500 \mathrm{~m}^{2} \mathrm{~g}^{-1}$, which delivers capacitances of $200 \mathrm{~F} \mathrm{~g}^{-1}$ and $100 \mathrm{~F} \mathrm{~g}^{-1}$ in aqueous and organic electrolytes, respectively [36,59]. Graphene is a promising material as a negative electrode $[32,60]$. A three-dimensional exfoliated graphene network has a mesoporous structure and excellent conductivity, enabling a high capacitance of up to $330 \mathrm{~F} \mathrm{~g}^{-1}$ that is superior to other AC-based electrodes [61]. However, the highly expensive or tedious work needed to synthesize graphene can hinder their large-scale production and practical use. This is the same case for CNTs. The more common aspect of graphene, CNTs, or activated carbon is that these electrode materials can hardly be used as free-standing electrodes and their surfaces are difficult to modify due to their powdered form and tendency to quickly aggregate. Self-supported electrode materials are necessary to make a device function independently. CC is promising as a self-supporting highly conductive substrate with high strength and flexibility. However, CC by itself has an extremely low capacitance due to its small surface area $\left(<10 \mathrm{~m}^{2} \mathrm{~g}^{-1}\right)$ and larger size compared to nanostructured materials. Recently, the activation of CC to increase its surface area has been considered a prominent strategy for achieving anode materials with a high capacitance [62]. Increasing the surface area of a material is a prime strategy since the surface is involved in ion adsorption and desorption at the electrode-electrolyte interface of an EDLC $[63,64]$. Moreover, the functionalization of carbon cloth materials also improves their performance by increasing conductivity and accommodating other double layer capacitance-contributing materials [65-67]. Porous nitrogen-doped carbon cloth exhibits a capacitance of $190 \mathrm{~F} \mathrm{~g}^{-1}$ [68]. Heterodoping on a mesoporous and functionalized CC can further increase the capacitance while exhibiting a wide working potential [58]. Tiwari et al. [58] reported an amorphous cobalt phosphate particle-anchored CC with $\mathrm{N}-\mathrm{P}$-doped porous carbon that delivered a capacitance of $606.1 \mathrm{~F} \mathrm{~g}^{-1}$ at a current density of $1 \mathrm{~A} \mathrm{~g}^{-1}$, which is significantly higher than that of the corresponding nonfunctionalized 
materials. Furthermore, these electrodes work over a wide potential range $(-1.4$ to +0.5$)$ in an aqueous $\mathrm{KOH}$ electrolyte (Figure 1), thereby opening a new avenue to produce a high-performance symmetrical supercapacitor. Moreover, they have shown that the as-assembled symmetrical device exhibited an energy density up to $31.1 \mathrm{~W} \mathrm{~h} \mathrm{~kg}^{-1}$ at a power density of $476.0 \mathrm{~W} \mathrm{~kg}^{-1}$ while demonstrating exceptional stability $(94.2 \%)$. The superior performance of the above device among contemporary devices was attributed to the amorphous carbon/cobalt phosphate composite and additional doping of P. Another report also suggested that doping $\mathrm{P}$ in amorphous materials can widen the working potential window, thereby increasing the energy density of the device [69].
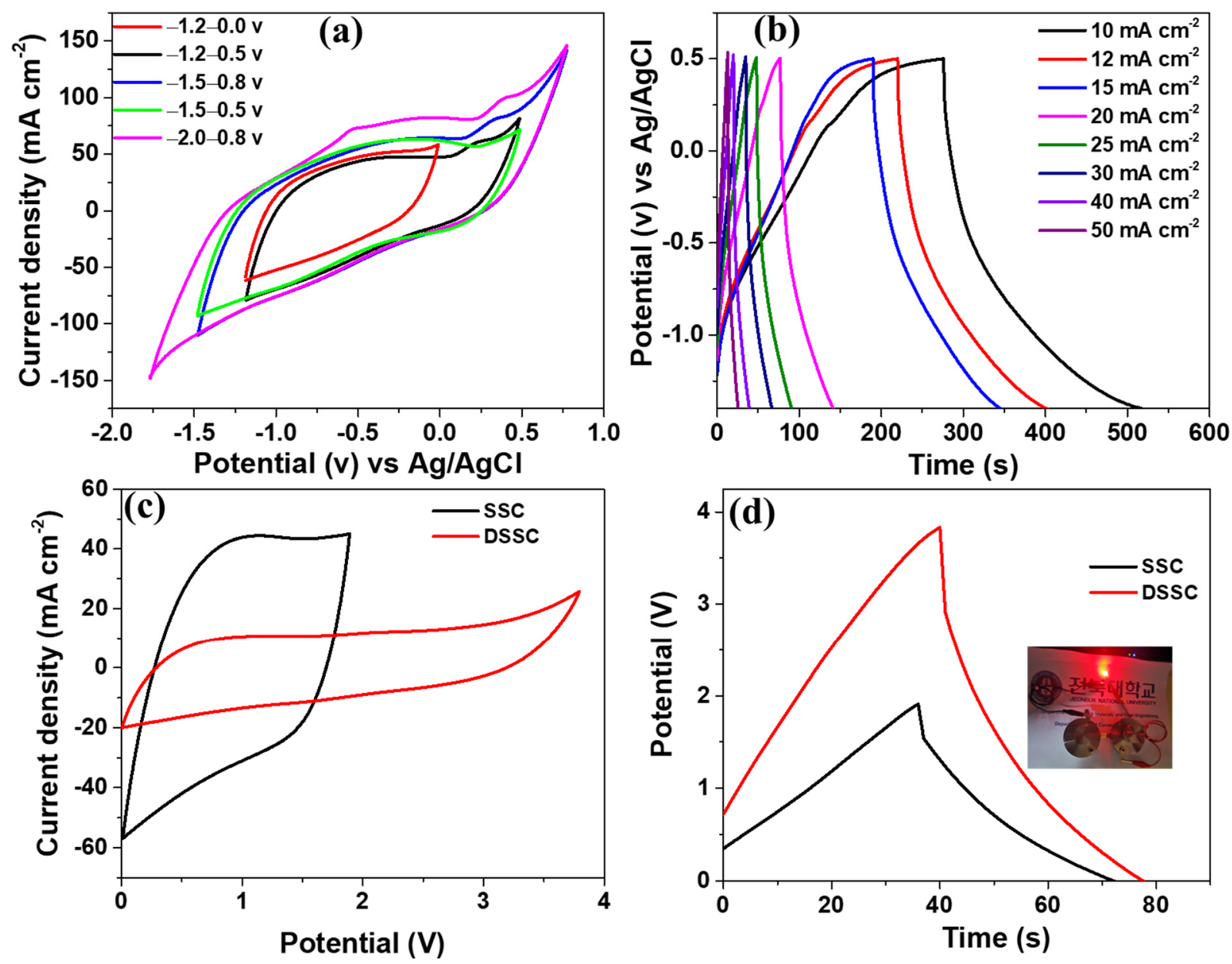

Figure 1. CV curves of a-PC@CoPi-CC8 within different potential windows at $50 \mathrm{mV} \mathrm{s}{ }^{-1}$ (a), GCD curves of the same sample at different current densities at potential ranges from -1.4 to $0.5(\mathbf{b})$. CV profiles of a symmetric supercapacitor (SSC) and a double SSC (DSSC) assembled from a-PC@CoPi-CC8 and collected at $50 \mathrm{mV} \mathrm{s}^{-1}$ (c), and GCD curves of the SSC and DSSC devices collected at $20 \mathrm{~mA} \mathrm{~cm}^{-2}$ (d). Inset is the image of a red light-emitting diode (LED) powered by two SSCs in series. The supercapacitor devices were charged for approximately $40 \mathrm{~s}$ before the LED tests. Reprinted with permission [58].

\section{Electrospun-Based Fibers as Negative Electrode Materials for Supercapacitors}

Currently, electrospun carbon nanofibers (ECNFs) have appeared as a promising material for electrochemical energy storage [32,38,59]. Most importantly, electrospun fibers can be produced with a simple machine in a laboratory setting, unlike the need for a company set up to produce carbon cloth. CNFs can be fabricated by the cost-effective and convenient electrospinning of organic polymers followed by carbonization [70-72]. Electrospinning is a method for the facile fabrication of nanofibers under the influence of an external electric field. It allows the fabrication of continuous fibers with nano- to 
microscale diameters [73-75]. In 1887, C. V. Boys showed that fibers could be produced from a viscoelastic liquid in the presence of an external electric field [76]. In 1902, J. F. Cooley and J. Martin filed patents for a prototype setup for electrospinning [71]. In 1964-1969, Geoffery Taylor reported a mathematical model for the formation of a Taylor cone from a spherical solution droplet under the influence of an external electrical field [77-79]. After the 1990s, various organic polymers were demonstrated to form nanofibers, and, after the 2000s, composites, ceramics, core-shell structures, hollow structures, and various types of nanofibers were produced [80-84]. Currently, electrospinning is a versatile method for the facile production of nanofibrous structures with diverse structures and functionalities for a variety of advanced technologies. The morphology, structure, and functionality of the nanofibrous material are determined by the nature of the polymer, solvent, and processing parameters [85,86]. Currently, a large number of natural and synthetic polymers have been successfully reported for the fabrication of nanofibers by electrospinning [71]. By incorporating active nanomaterials or precursors, electrospun nanofibers can be used as advanced functional materials for a variety of technologies, such as air filtration, including face masks, water filtration; oil-water separation; energy storage and conversion; catalysis; biomedical use; textiles. The postmodification of nanofibers is essential for obtaining structural and functional variations, as demanded by various technologies. A typical electrospinning setup is illustrated in Figure 2.
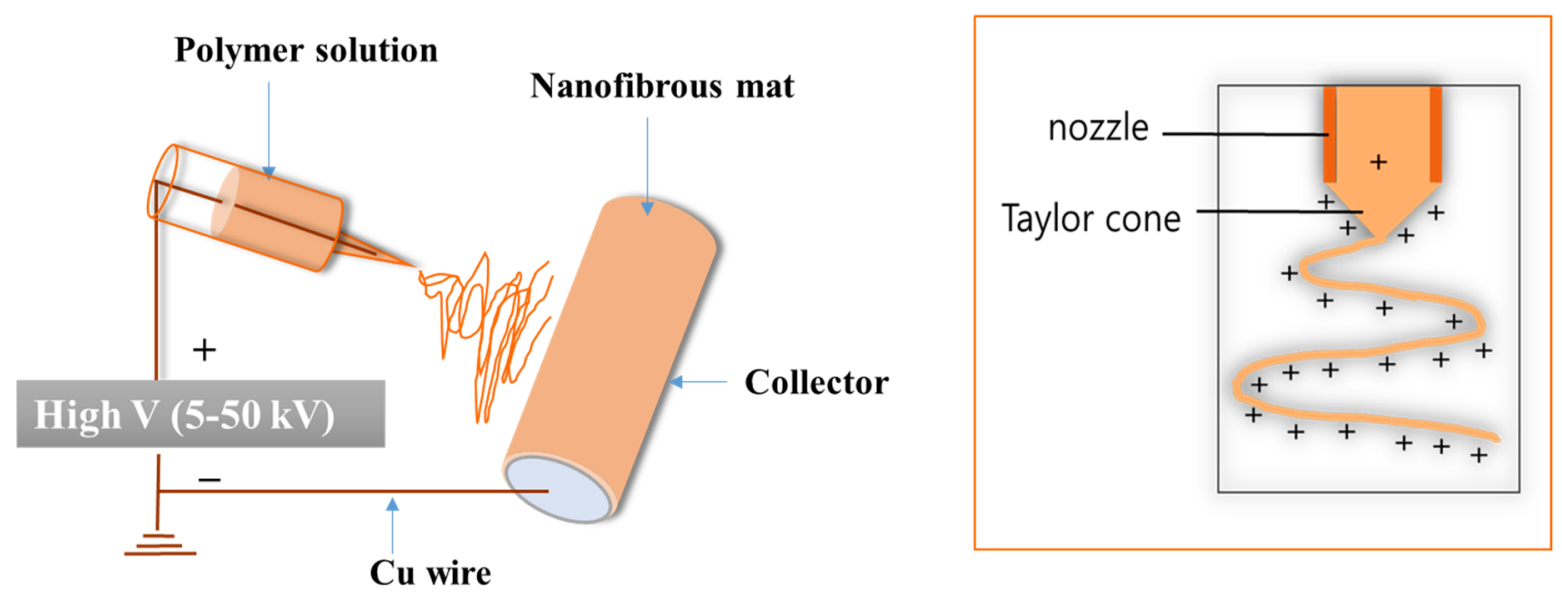

Figure 2. Schematic representing the simple electrospinning process.

CNF sheets consist of very long nonwoven one-dimensional (1D) carbon nanofibers that form 2D sheets that can be modified as necessary. The large specific surface area, chemical stability, lightweight, good conductivity, easy accessibility, and environmentally friendly nature of CNFs are attractive features. In addition, CNFs possess other advantages: (i) CNFs are very economical compared to graphene and carbon nanotubes and can be easily fabricated on a mass scale. (ii) With proper modifications of the electrospinning technique, precursor composition, or position, followed by a postmodification, carbon nanofibers with extraordinary porosity, a large specific surface area, and diverse functionalities can be fabricated [87-92]. (iii) CNFs can be directly used as a free-standing electrode without the use of a conductive additive, binder, or current collector. The use of binders and additives decreases the effective surface area and conductivity of the electrode, thereby decreasing its performance [93]. ECNF sheets as current collectors instead of heavy metals, such as nickel foam, significantly reduce the weight of electrodes [94,95]. (iv) CNF sheets offer a light and chemically stable 1D nanoskeleton for the growth of various active nanostructures in 3D patterns without aggregation and can be used as free-standing electrodes [96,97]. (v) CNFs offer a larger specific surface area and conductive network than the same mass of carbon cloth since the fibers in carbon cloth are microscale. (vi) Finally, CNFs can be used as flexible electrodes. Therefore, electrospun carbon nanofiber sheets are very attractive for energy 
storage applications [98,99]. Moreover, the modification of CNFs to obtain an increased capacitance can be done in two ways. First, the electrospinning process is performed by tuning the electrospinning solution parameters and processing parameters. Second, modifications can be done by post-CNF synthesis processes [32,59]. The post-modification approaches for increasing capacitance are more or less similar to those of CC.

The most commonly used polymer to synthesize carbon nanofibers is PAN due to its high carbon yield compared to other polymers. Other polymers used for that purpose are shown in Table 2. Various processing parameters, such as the voltage, flow rate, and collector-to-tip distance, along with solution parameters, such as the viscosity and conductivity of a polymer solution, can play a role in controlling the morphology and fiber diameter of the final product. Pure, as-spun polymeric nanofibers generally have low conductivity; therefore, stepwise thermal treatment processes, such as stabilization and subsequent carbonization, must be performed to make the carbon fibers more conductive. The potential of electrospun carbon nanofiber-based materials in diverse advanced technologies has been increasingly studied, and progress has been summarized in a few reviews. However, works related to electrospun carbon nanofiber-based negative electrode materials for supercapacitors have been rarely summarized. We believe this review can serve as a resource for further studies on the development of negative electrode materials for high-performance energy storage devices.

Typically, ECNFs are solid and have a small surface area that results in low capacitance and energy density. To this end, it is necessary to design carbon fibers to increase the surface area and make composites with materials that can contribute to a high capacitance, while not hampering the inherent features of carbon fibers. Nanofibrous materials with a high specific surface area, controllable porosity, good conductivity, and flexibility are promising features for next-generation technologies. Therefore, different strategies have been adopted to fabricate nanofibers with such properties. Coaxial electrospinning produces sheath-core nanofibers. It uses a coaxial needle that consists of inner and outer hollow needles that are arranged concentrically and dispense two different solutions. By using less volatile or washable core polymers, hollow nanofibers can be obtained [83]. Coaxial electrospinning using poly(methyl methacrylate) (PMMA) as the core solution and a PAN solution as the shell solution, thereby producing PMMA/PAN core-shell nanofibers. Regarding the PMMA/PAN nanofibers after carbonization, a more volatile PMMA portion is removed; therefore, hollow carbon nanofibers are obtained (Figure 3b) [88]. Electrospinning PAN/PMMA blends with different ratios produce multiporous nanofibers (Figure 3c) [100].

Using block copolymer-based precursors as an approach is significant for controlling the porosity of the resulting material and may revolutionize the synthesis of PCNFs [91]. Zhou et al. synthesized dual-doped PCNFs with well-controlled bimodal pores, namely, mesopores $(10 \mathrm{~nm})$ and micropores $(0.5 \mathrm{~nm})$, by electrospinning poly(acrylonitrile-block-methyl methacrylate) (Figure 3f) [91]. There are some other notable reports. Yan et al. prepared highly porous sponge-like carbon nanofibers by electrospinning poly(tetrafluoroethylene) and poly(vinyl alcohol) with boric acid as the crosslinking agent. These nanofibers possessed well-controlled macro/meso/micropores and an ultrahigh porosity $(>80 \%)$ and outstanding conductivity $\left(980 \mathrm{~S} \mathrm{~cm}^{-1}\right)$, while being triple-doped with B-F-N (Figure 3g) [103]. Yang et al. prepared necklace-like hollow carbon nanofibrous materials with an abundance of micro/meso/micropores and an ultrahigh content of doped N (Figure 3h) [104]. One of the common strategies for fabricating porous nanofibers is the selective removal of a sacrificial phase from the as-spun nanofibers by washing, leaching, or heating. The sacrificial phase may be small nanoparticles or another polymer. Wang et al. fabricated silicon oxide $\left(\mathrm{SiO}_{2}\right)$ - and $\mathrm{Sb}$-entrapped nanofibers by electrospinning antimony trichloride $\left(\mathrm{SbCl}_{3}\right)$, polyvinylpyrrolidone (PVP), and tetraethylorthosilicate (TEOS). After carbonization and etching with HF, a highly porous carbon nanofibrous structure was obtained (Figure 3d) [102]. They later used this electrode as a highly stable electrode for Li batteries. 


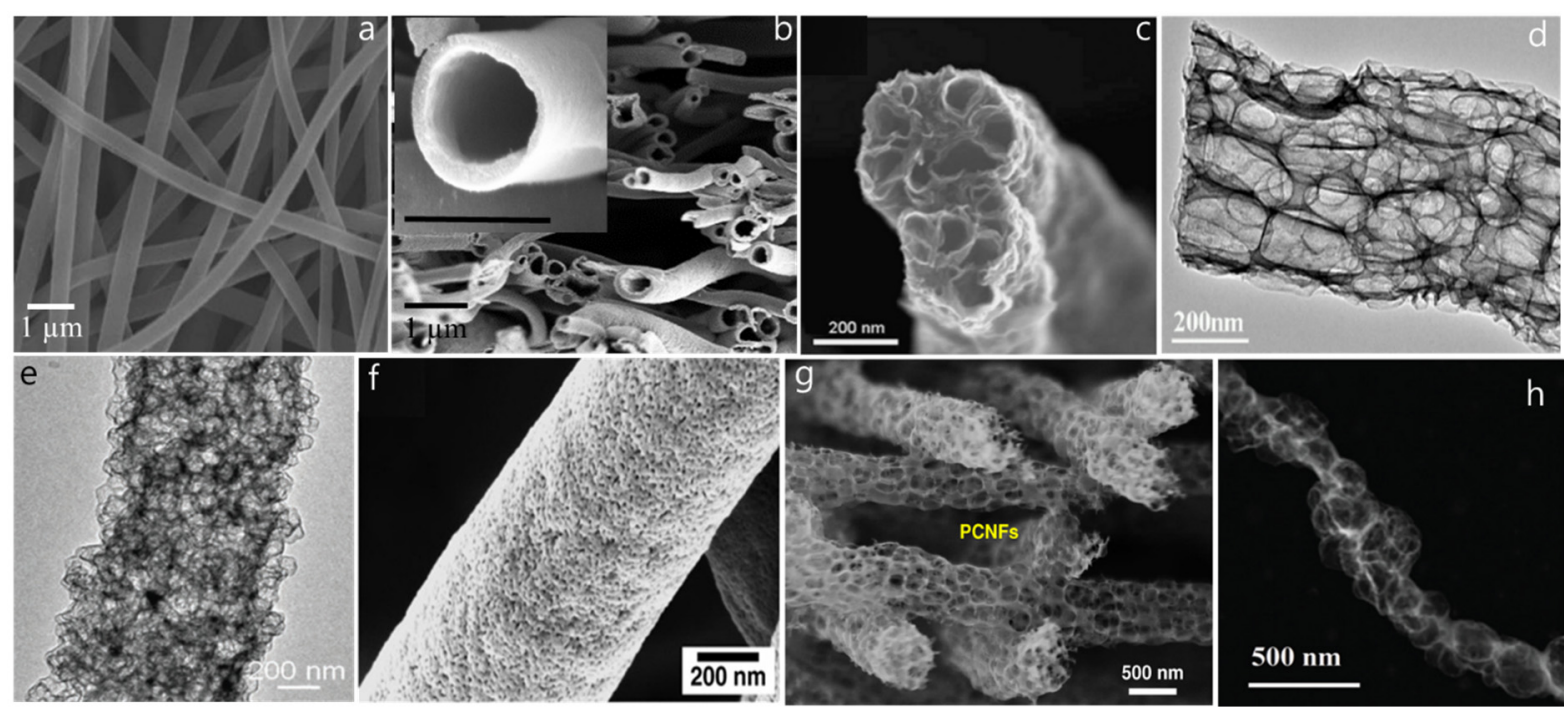

Figure 3. (a) SEM image of a CNF obtained by electrospinning PAN. (b) Field emission electron microscopy (FESEM) image of a hollow carbon nanofiber (HCNF) prepared by the coaxial electrospinning of PAN/PMMA (scale of the inset is $500 \mathrm{~nm}$ ). (c) FESEM image of a porous carbon nanofiber (PCNF) prepared by electrospinning a PAN/PMMA blend and treated at $2800{ }^{\circ} \mathrm{C}$. (d) Transmission electron microscopy (TEM) image of macroporous CNFs obtained by etching silicareinforced carbon nanofibers with encapsulated antimony $(\mathrm{Sb})$ nanoparticles $\left(\mathrm{SiO}_{2} / \mathrm{Sb} @ \mathrm{CNF}\right)$ composite with an aqueous hydrogen fluoride (HF) solution. (e) TEM image of an N-doped PCNF prepared by a metal-organic framework (MOF)-based approach. (f) FESEM image of a PCNF by electrospinning a poly(acrylonitrile-block-methyl methacrylate) polymer. (g) SEM image of a triple-doped B-N-F sponge-like PCNF. (h) TEM image of an N-doped necklace-like HCNF. (a) Reprinted with permission [101], Copyright Elsevier 2019. (b) Reprinted with permission [88], Copyright American Chemical Society 2020. (c) Reprinted with permission [100], Copyright 2007, Wiley-VCH. (d) Reprinted with permission [102], Copyright American Chemical Society 2018. (e) Reprinted with permission [44], Copyright The Royal Society of Chemistry 2017. (f) Reprinted with permission [91], Copyright Science Advances 2019 (g) Reprinted with permission [103], Copyright Springer Nature 2019. (h) Reprinted with permission [104], Copyright The Royal Society of Chemistry 2019.

A new strategy for the fabrication of highly porous nanofibers is the use of MOFs. MOFs, such as zeolitic imidazolate frameworks (ZIF-8, ZIF-67), can be directly developed in nanofibers during electrospinning or at later stages. MOFs are interesting new nanomaterials because of their unique and controllable features, such as their high porosity, large specific surface area, and variability in regard to metal ions and organic linkers; thus, they are attractive for a wide range of applications [105-109]. Chen et al. fabricated ZIF-8mediated highly porous nitrogen-doped carbon nanofibers (Figure 3e) [44] that showed capacitances up to $307.2 \mathrm{~F} \mathrm{~g}^{-1}$ at a current density of $1 \mathrm{~A} \mathrm{~g}^{-1}$; additionally, this material retained a capacitance of $193.3 \mathrm{~F} \mathrm{~g}^{-1}$ at $50 \mathrm{~A} \mathrm{~g}^{-1}$ [44]. This high-value achievement was attributed to the superior Brunauer-Emmett-Teller (BET) surface area of the ZIF-8-induced porous ECNFs. The BET surface area was observed to be almost 50 times that of pure ECNFs. Therefore, compared to conventional materials, MOF-based nanomaterials usually exhibit a controllable porous architecture and pore volume along with an extraordinarily large surface area [108,110-114]. Furthermore, no additional template is required for promoting porosity. Heteroatom doping, which enhances the electronic properties of a material, needs additional chemicals and processes that may be complicated and hazardous. In the case of MOF-derived materials, the heteroatoms present in organic ligands, such as 2-methylimidazole, are directly doped and do not require additional chemicals or steps.

Another benefit of carbon nanofibers is their use as one of the constituents of nanocomposites or simply as light and conductive substrates for the growth of active materials. Different nanocarbons, such as graphene and CNTs, as well as many metal compounds, such as hydroxides, oxides, sulfides, and phosphides, in a number of shapes and sizes, have been engineered on CNFs to produce a variety of architectures. Qie et al. developed graphene-reinforced ECNFs that exhibited a specific capacitance of $183 \mathrm{~F} \mathrm{~g}^{-1}$, approx- 
imately 1.6 times higher than that of pristine CNFs [47]. Few reports have shown the growth of metal-based compounds on ECNFs as negative electrode materials for supercapacitors $[115,116]$. The optimal concentration of metal doping can be beneficial to obtain high capacitance without sacrificing EDLC behavior and the high conductivity of the carbon materials. Otherwise, the composite simply becomes a composite that demonstrates metal-dominated behavior, i.e., high Faradic activity and low stability [58].

Table 2. Precursors to obtain carbon fibers, their application, and properties.

\begin{tabular}{|c|c|c|c|c|}
\hline S.N. & Polymer/Solvent & $\begin{array}{c}\text { Fiber Diameter/Surface } \\
\text { Area }\end{array}$ & Application & References \\
\hline 1 & $\begin{array}{l}\text { Polyacrylonitrile / dimethylformaide } \\
\text { (PAN/DMF) with a metal precursor }\end{array}$ & $200-500 \mathrm{~nm} / \mathrm{N} / \mathrm{A}$ & Energy storage & {$[59,88,117]$} \\
\hline 2 & Coal, PAN/DMF & $\mathrm{N} / \mathrm{A}$ & Energy storage & {$[118]$} \\
\hline 3 & {$[\mathrm{PAN}+\mathrm{PMMA}+$ tin octoate] $/ \mathrm{DMF}$} & $\mathrm{N} / \mathrm{A}$ & Lithium-based batteries & [119] \\
\hline 4 & $\begin{array}{l}\text { PVP, cobalt nitrate }\left[\mathrm{Co}\left(\mathrm{NO}_{3}\right)\right] \text { in } \\
\text { water/ethanol }\end{array}$ & $150 \mathrm{~nm} / \mathrm{N} / \mathrm{A}$ & Sodium ion batteries & {$[120]$} \\
\hline 5 & ZIF-67, PAN/DMF & $200 \mathrm{~nm} / 338.37 \mathrm{~m}^{2} \mathrm{~g}^{-1}$ & Li-S batteries & {$[121]$} \\
\hline 6 & PAN, cobalt salt/DMF & & Energy storage & {$[32]$} \\
\hline 7 & PAN, terephthalic acid/DMF & $400-600 \mathrm{~nm} / \mathrm{N} / \mathrm{A}$ & Electrochemical test & [122] \\
\hline 8 & Pitch/DMF & Micrometer/N/A & Gas diffusion & {$[123]$} \\
\hline 9 & $\begin{array}{l}\text { Polyimide/dimethylacetamide } \\
\text { (PI/DMAc) }\end{array}$ & Micrometer/N/A & $\mathrm{n} / \mathrm{a}$ & {$[124]$} \\
\hline 10 & Cellulose/acetone-dimethylacetamide & $50-500 \mathrm{~nm} / \mathrm{N} / \mathrm{A}$ & Energy storage & {$[125]$} \\
\hline 11 & PVP, ammonia borane/methanol & $150 \mathrm{~nm} / 145 \mathrm{~m}^{2} \mathrm{~g}^{-1}$ & Lithium-ion batteries & {$[126]$} \\
\hline 12 & $\begin{array}{l}\text { Lignin, polyvinyl alcohol/distilled water } \\
\text { (PVA/DW) }\end{array}$ & $100 \pm 23 \mathrm{~nm} / 1670 \mathrm{~m}^{2} \mathrm{~g}^{-1}$ & Energy storage & {$[127]$} \\
\hline 14 & PAN, PVDF/DMF & $200-300 \mathrm{~nm} / 29 \mathrm{~m}^{2} \mathrm{~g}^{-1}$ & $\mathrm{CO}_{2}$ adsorbents & {$[128]$} \\
\hline 15 & Plant protein/acetic acid & $413-900 \mathrm{~nm} / \mathrm{N} / \mathrm{A}$ & Energy storage & [129] \\
\hline
\end{tabular}

\section{Challenges, Opportunities, and Future Directions}

Generally, carbon fibers are brittle; therefore, it is very challenging to retain fibers in their free-standing and flexible state. There are some reports that show the successful fabrication of highly flexible carbon fibers, and they have been used to study electrochemical performance $[130,131]$. Tian et al. showed interconnected networks of carbon fibers that improved the integrity and buffered the volume expansion of an electrode, while contributing to its flexibility [132]. Similarly, Liu et al. [33] synthesized highly flexible electrospun-based carbon fibers from pitch using a crosslinking strategy. The as-designed product exhibited a capacitance of $170 \mathrm{~F} \mathrm{~g}^{-1}$ at a current density of $1 \mathrm{~A} \mathrm{~g}^{-1}$. Another challenge is to make a three-dimensional flexible network. As-spun membrane-derived carbon fibers are similar to a two-dimensional sheet composed of compacted fibers. In such a case, the modification of fibers by electrochemically active materials to achieve high performance can be limited to only the surface of exposed fibers, and the remaining internally located fibers of the membrane remain untouched [32]. Recently, the fabrication of three-dimensional foam-like carbonaceous structures has been reported [28,32,133]. For instance, electrospinning and subsequent post-processing (gas foaming) result in a three-dimensional network structure. Tiwari et al. $[28,32]$ recently demonstrated a three-dimensional carbonaceous porous network that exhibited high capacitances up to $205 \mathrm{~F} \mathrm{~g}^{-1}$ at a current density of $1 \mathrm{~A} \mathrm{~g}^{-1}$. The PAN nanofibrous mats were first fabricated in a three-dimensional shape by sodium borohydride-mediated hydrolysis, causing hydrogen gas to become trapped into the fibrous network. Later, these were carbonized to obtain carbon fibers. Current challenges 
can become opportunities in the future. The synthesis of highly flexible carbon nanofibers with a high capacitance that work over a wide range of potentials can be a future opportunity. Recently, MOFs have become promising materials for the development of porous and highly branched crosslinked networks $[134,135]$. In this context, the integration of MOF-derived networks into porous and hollow carbon nanofibers with negative electrode materials can overcome the challenges associated with pure carbon nanofibers, such as their brittleness, inflexibility, low capacitance, and low energy density. It is expected that the highly flexible free-standing configuration of ECNF membranes will be an option for developing the next generation of flexible energy storage devices.

\section{Conclusions}

In this review, we reported the ECNF-based negative electrode materials used in supercapacitors. Among the many carbonaceous materials, ECNFs have many advantages, such as the possibility of developing free-standing materials and their ability to accommodate other active compounds to achieve higher performances. Strategies to obtain higher capacitance by modifying ECNFs without disturbing the EDLC behavior of carbon nanofibers were discussed in this report. By reviewing the literature and providing critical analysis, it was found that the creation of highly porous networks along with metal doping and heteroatom doping are promising strategies for developing anode materials with high capacitance values. We expect that the shortcomings of pure ECNFs in energy storage can be overcome by the use of secondary techniques and strategies. Overall, this review explores the negative electrode materials used thus far and provides insight for the further development of high-performance supercapacitors to use in next-generation devices.

Funding: This research was supported by the Program for Fostering the Next Generation of Researchers in engineering of the National Research Foundation of Korea (NRF) funded by the Ministry of Science, ICT (No. 2017H1D8A2030449).

Institutional Review Board Statement: Not applicable.

Informed Consent Statement: Not applicable.

Data Availability Statement: Not applicable.

Conflicts of Interest: There is no conflict of interest.

\section{References}

1. Gür, T.M. Review of electrical energy storage technologies, materials and systems: Challenges and prospects for large-scale grid storage. Energy Environ. Sci. 2018, 11, 2696-2767. [CrossRef]

2. Agency, I.E. World Energy Outlook 2018. 2018. Available online: https://www.oecd-ilibrary.org/energy/world-energy-outlook2018_weo-2018-en (accessed on 1 November 2020).

3. Jin, H.; Li, J.; Yuan, Y.; Wang, J.; Lu, J.; Wang, S. Recent Progress in Biomass-Derived Electrode Materials for High Volumetric Performance Supercapacitors. Adv. Energy Mater. 2018, 8, 1801007. [CrossRef]

4. Capellán-Pérez, I.; Arto, I.; Polanco-Martínez, J.M.; González-Eguino, M.; Neumann, M.B. Likelihood of climate change pathways under uncertainty on fossil fuel resource availability. Energy Environ. Sci. 2016, 9, 2482-2496. [CrossRef]

5. Khan, N.; Dilshad, S.; Khalid, R.; Kalair, A.R.; Abas, N. Review of energy storage and transportation of energy. Energy Storage 2019, 1, e49. [CrossRef]

6. Palacín, M.R.; de Guibert, A. Why do batteries fail? Science 2016, 351, 1253292. [CrossRef]

7. El Kharbachi, A.; Zavorotynska, O.; Latroche, M.; Cuevas, F.; Yartys, V.; Fichtner, M. Exploits, advances and challenges benefiting beyond Li-ion battery technologies. J. Alloys Compd. 2020, 817, 153261. [CrossRef]

8. Simon, P.; Gogotsi, Y.; Dunn, B. Where Do Batteries End and Supercapacitors Begin? Science 2014, 343, 1210. [CrossRef]

9. Zhou, Y.; Wang, C.-H.; Lu, W.; Dai, L. Recent Advances in Fiber-Shaped Supercapacitors and Lithium-Ion Batteries. Adv. Mater. 2020, 32, 1902779. [CrossRef]

10. Gou, Q.; Zhao, S.; Wang, J.; Li, M.; Xue, J. Recent Advances on Boosting the Cell Voltage of Aqueous Supercapacitors. Nano Micro Lett. 2020, 12, 98. [CrossRef]

11. Bi, Z.; Kong, Q.; Cao, Y.; Sun, G.; Su, F.; Wei, X.; Li, X.; Ahmad, A.; Xie, L.; Chen, C.-M. Biomass-derived porous carbon materials with different dimensions for supercapacitor electrodes: A review. J. Mater. Chem. A 2019, 7, 16028-16045. [CrossRef]

12. Merlet, C.; Rotenberg, B.; Madden, P.A.; Taberna, P.-L.; Simon, P.; Gogotsi, Y.; Salanne, M. On the molecular origin of supercapacitance in nanoporous carbon electrodes. Nat. Mater. 2012, 11, 306-310. [CrossRef] [PubMed] 
13. Yu, Z.; Tetard, L.; Zhai, L.; Thomas, J. Supercapacitor electrode materials: Nanostructures from 0 to 3 dimensions. Energy Environ. Sci. 2015, 8, 702-730. [CrossRef]

14. Chen, H.; Hu, L.; Chen, M.; Yan, Y.; Wu, L. Nickel-cobalt layered double hydroxide nanosheets for high-performance supercapacitor electrode materials. Adv. Funct. Mater. 2014, 24, 934-942. [CrossRef]

15. Liang, H.; Jia, H.; Lin, T.; Wang, Z.; Li, C.; Chen, S.; Qi, J.; Cao, J.; Fei, W.; Feng, J. Oxygen-vacancy-rich nickel-cobalt layered double hydroxide electrode for high-performance supercapacitors. J. Colloid Interface Sci. 2019, 554, 59-65. [CrossRef] [PubMed]

16. Yang, J.; Yu, C.; Hu, C.; Wang, M.; Li, S.; Huang, H.; Bustillo, K.; Han, X.; Zhao, C.; Guo, W.; et al. Surface-Confined Fabrication of Ultrathin Nickel Cobalt-Layered Double Hydroxide Nanosheets for High-Performance Supercapacitors. Adv. Funct. Mater. 2018, 28, 1803272. [CrossRef]

17. Wei, Z.; Yuan, J.; Tang, S.; Wu, D.; Wu, L. Porous nanorods of nickel-cobalt double hydroxide prepared by electrochemical co-deposition for high-performance supercapacitors. J. Colloid Interface Sci. 2019, 542, 15-22. [CrossRef]

18. Li, L.; Zhang, M.; Zhang, X.; Zhang, Z. New $\mathrm{Ti}_{3} \mathrm{C}_{2}$ aerogel as promising negative electrode materials for asymmetric supercapacitors. J. Power Sources 2017, 364, 234-241. [CrossRef]

19. Grote, F.; Zhao, H.; Lei, Y. Self-supported carbon coated TiN nanotube arrays: Innovative carbon coating leads to an improved cycling ability for supercapacitor applications. J. Mater. Chem. A 2015, 3, 3465-3470. [CrossRef]

20. Han, X.; Zhang, D.; Qin, Y.; Kong, X.; Zhang, F.; Lei, X. Construction of Ta-Cu7S4 negative electrode for high-performance all-solid-state asymmetric supercapacitor. Chem. Eng. J. 2021, 403, 126471. [CrossRef]

21. Sun, G.; Ren, H.; Shi, Z.; Zhang, L.; Wang, Z.; Zhan, K.; Yan, Y.; Yang, J.; Zhao, B. V2O5/vertically-aligned carbon nanotubes as negative electrode for asymmetric supercapacitor in neutral aqueous electrolyte. J. Colloid Interface Sci. 2021, 588, 847-856. [CrossRef]

22. Zheng, K.; Zeng, Y.; Liu, S.; Zeng, C.; Tong, Y.; Zheng, Z.; Zhu, T.; Lu, X. Valence and surface modulated vanadium oxide nanowires as new high-energy and durable negative electrode for flexible asymmetric supercapacitors. Energy Storage Mater. 2019, 22, 410-417. [CrossRef]

23. Zhang, T.; Kong, L.-B.; Liu, M.-C.; Dai, Y.-H.; Yan, K.; Hu, B.; Luo, Y.-C.; Kang, L. Design and preparation of MoO2/MoS2 as negative electrode materials for supercapacitors. Mater. Des. 2016, 112, 88-96. [CrossRef]

24. Upadhyay, K.K.; Nguyen, T.; Silva, T.M.; Carmezim, M.J.; Montemor, M.F. Electrodeposited MoOx films as negative electrode materials for redox supercapacitors. Electrochim. Acta 2017, 225, 19-28. [CrossRef]

25. Long, C.; Wei, T.; Yan, J.; Jiang, L.; Fan, Z. Supercapacitors based on graphene-supported iron nanosheets as negative electrode materials. ACS Nano 2013, 7, 11325-11332. [CrossRef]

26. Luo, J.; Zheng, Z.; Kumamoto, A.; Unah, W.I.; Yan, S.; Ikuhara, Y.H.; Xiang, X.; Zu, X.; Zhou, W. PEDOT coated iron phosphide nanorod arrays as high-performance supercapacitor negative electrodes. Chem. Commun. 2018, 54, 794-797. [CrossRef]

27. Liang, B.; Zheng, Z.; Retana, M.; Lu, K.; Wood, T.; Ai, Y.; Zu, X.; Zhou, W. Synthesis of FeP nanotube arrays as negative electrode for solid-state asymmetric supercapacitor. Nanotechnology 2019, 30, 295401. [CrossRef]

28. Tiwari, A.P.; Chhetri, K.; Kim, H.; Ji, S.; Chae, S.-H.; Kim, T.; Kim, H.Y. Self-assembled polypyrrole hierarchical porous networks as the cathode and porous three dimensional carbonaceous networks as the anode materials for asymmetric supercapacitor. $J$. Energy Storage 2021, 33, 102080. [CrossRef]

29. Hsu, Y.-H.; Lai, C.-C.; Ho, C.-L.; Lo, C.-T. Preparation of interconnected carbon nanofibers as electrodes for supercapacitors. Electrochim. Acta 2014, 127, 369-376. [CrossRef]

30. Yang, Z.-Y.; Zhao, Y.-F.; Xiao, Q.-Q.; Zhang, Y.-X.; Jing, L.; Yan, Y.-M.; Sun, K.-N. Controllable Growth of CNTs on Graphene as High-Performance Electrode Material for Supercapacitors. ACS Appl. Mater. Interfaces 2014, 6, 8497-8504. [CrossRef]

31. Zhi, M.; Liu, S.; Hong, Z.; Wu, N. Electrospun activated carbon nanofibers for supercapacitor electrodes. RSC Adv. 2014, 4, 43619-43623. [CrossRef]

32. Tiwari, A.P.; Chae, S.-H.; Ojha, G.P.; Dahal, B.; Mukhiya, T.; Lee, M.; Chhetri, K.; Kim, T.; Kim, H.-Y. Three-dimensional porous carbonaceous network with in-situ entrapped metallic cobalt for supercapacitor application. J. Colloid Interface Sci. 2019, 553, 622-630. [CrossRef] [PubMed]

33. Tian, X.; He, Y.; Song, Y.; Yang, T.; Li, X.; Liu, Z. Flexible Cross-Linked Electrospun Carbon Nanofiber Mats Derived from Pitch as Dual-Functional Materials for Supercapacitors. Energy Fuels 2020, 34, 14975-14985. [CrossRef]

34. Zheng, S.; Li, Q.; Xue, H.; Pang, H.; Xu, Q. A highly alkaline-stable metal oxide@ metal-organic framework composite for high-performance electrochemical energy storage. Natl. Sci. Rev. 2020, 7, 305-314. [CrossRef]

35. Siraj, N.; Macchi, S.; Berry, B.; Viswanathan, T. Metal-Free Carbon-Based Supercapacitors-A Comprehensive Review. Electrochem 2020, 1, 410-438. [CrossRef]

36. Frackowiak, E. Carbon materials for supercapacitor application. Phys. Chem. Chem. Phys. 2007, 9, 1774-1785. [CrossRef]

37. Denmark, I.; Macchi, S.; Watanabe, F.; Viswanathan, T.; Siraj, N. Effect of KOH on the Energy Storage Performance of MolassesBased Phosphorus and Nitrogen Co-Doped Carbon. Electrochem 2021, 2, 29-40. [CrossRef]

38. Wang, L.; Zhang, G.; Zhang, X.; Shi, H.; Zeng, W.; Zhang, H.; Liu, Q.; Li, C.; Liu, Q.; Duan, H. Porous ultrathin carbon nanobubbles formed carbon nanofiber webs for high-performance flexible supercapacitors. J. Mater. Chem. A 2017, 5, 14801-14810. [CrossRef]

39. Kshetri, T.; Tran, D.T.; Nguyen, D.C.; Kim, N.H.; Lau, K.-T.; Lee, J.H. Ternary graphene-carbon nanofibers-carbon nanotubes structure for hybrid supercapacitor. Chem. Eng. J. 2020, 380, 122543. [CrossRef] 
40. Song, B.; Wu, F.; Zhu, Y.; Hou, Z.; Moon, K.-s.; Wong, C.-P. Effect of polymer binders on graphene-based free-standing electrodes for supercapacitors. Electrochim. Acta 2018, 267, 213-221. [CrossRef]

41. Zhang, S.; Dai, P.; Liu, H.; Yan, L.; Song, H.; Liu, D.; Zhao, X. Metal-organic framework derived porous flakes of cobalt chalcogenides ( $\mathrm{CoX}, \mathrm{X}=\mathrm{O}, \mathrm{S}$, Se and $\mathrm{Te}$ ) rooted in carbon fibers as flexible electrode materials for pseudocapacitive energy storage. Electrochim. Acta 2021, 369, 137681. [CrossRef]

42. Dahal, B.; Mukhiya, T.; Ojha, G.P.; Muthurasu, A.; Chae, S.-H.; Kim, T.; Kang, D.; Kim, H.Y. In-built fabrication of MOF assimilated B/N co-doped 3D porous carbon nanofiber network as a binder-free electrode for supercapacitors. Electrochim. Acta 2019, 301, 209-219. [CrossRef]

43. Kshetri, T.; Tran, D.T.; Singh, T.I.; Kim, N.H.; Lau, K.-t.; Lee, J.H. Effects of the composition of reduced graphene oxide/carbon nanofiber nanocomposite on charge storage behaviors. Compos. Part B Eng. 2019, 178, 107500. [CrossRef]

44. Chen, L.-F.; Lu, Y.; Yu, L.; Lou, X.W. Designed formation of hollow particle-based nitrogen-doped carbon nanofibers for high-performance supercapacitors. Energy Environ. Sci. 2017, 10, 1777-1783. [CrossRef]

45. Chhetri, K.; Tiwari, A.P.; Dahal, B.; Ojha, G.P.; Mukhiya, T.; Lee, M.; Kim, T.; Chae, S.-H.; Muthurasu, A.; Kim, H.Y. A ZIF-8derived nanoporous carbon nanocomposite wrapped with $\mathrm{Co3O} 4$-polyaniline as an efficient electrode material for an asymmetric supercapacitor. J. Electroanal. Chem. 2020, 856, 113670. [CrossRef]

46. Zhang, P.; Sun, F.; Shen, Z.; Cao, D. ZIF-derived porous carbon: A promising supercapacitor electrode material. J. Mater. Chem. A 2014, 2, 12873-12880. [CrossRef]

47. Dong, Q.; Wang, G.; Hu, H.; Yang, J.; Qian, B.; Ling, Z.; Qiu, J. Ultrasound-assisted preparation of electrospun carbon nanofiber/graphene composite electrode for supercapacitors. J. Power Sources 2013, 243, 350-353. [CrossRef]

48. Chhetri, K.; Dahal, B.; Mukhiya, T.; Tiwari, A.P.; Muthurasu, A.; Kim, T.; Kim, H.; Kim, H.Y. Integrated hybrid of graphitic carbonencapsulated $\mathrm{CuxO}$ on multilayered mesoporous carbon from copper MOFs and polyaniline for asymmetric supercapacitor and oxygen reduction reactions. Carbon 2021, 179, 89-99. [CrossRef]

49. Xu, Q.; Yu, X.; Liang, Q.; Bai, Y.; Huang, Z.-H.; Kang, F. Nitrogen-doped hollow activated carbon nanofibers as high performance supercapacitor electrodes. J. Electroanal. Chem. 2015, 739, 84-88. [CrossRef]

50. Chen, L.-F.; Zhang, X.-D.; Liang, H.-W.; Kong, M.; Guan, Q.-F.; Chen, P.; Wu, Z.-Y.; Yu, S.-H. Synthesis of Nitrogen-Doped Porous Carbon Nanofibers as an Efficient Electrode Material for Supercapacitors. ACS Nano 2012, 6, 7092-7102. [CrossRef] [PubMed]

51. Ding, B.; Wu, X. Transition metal oxides anchored on graphene/carbon nanotubes conductive network as both the negative and positive electrodes for asymmetric supercapacitor. J. Alloys Compd. 2020, 842, 155838. [CrossRef]

52. Ishita, I.; Singhal, R. Porous multi-channel carbon nanofiber electrodes using discarded polystyrene foam as sacrificial material for high-performance supercapacitors. J. Appl. Electrochem. 2020, 50, 809-820. [CrossRef]

53. Sheng, J.; Ma, C.; Ma, Y.; Zhang, H.; Wang, R.; Xie, Z.; Shi, J. Synthesis of microporous carbon nanofibers with high specific surface using tetraethyl orthosilicate template for supercapacitors. Int. J. Hydrogen Energy 2016, 41, 9383-9393. [CrossRef]

54. Choudhury, A.; Kim, J.-H.; Sinha Mahapatra, S.; Yang, K.-S.; Yang, D.-J. Nitrogen-Enriched Porous Carbon Nanofiber Mat as Efficient Flexible Electrode Material for Supercapacitors. ACS Sustain. Chem. Eng. 2017, 5, 2109-2118. [CrossRef]

55. Ma, C.; Li, Y.; Shi, J.; Song, Y.; Liu, L. High-performance supercapacitor electrodes based on porous flexible carbon nanofiber paper treated by surface chemical etching. Chem. Eng. J. 2014, 249, 216-225. [CrossRef]

56. Zhu, T.; Zhou, J.; Li, Z.; Li, S.; Si, W.; Zhuo, S. Hierarchical porous and N-doped carbon nanotubes derived from polyaniline for electrode materials in supercapacitors. J. Mater. Chem. A 2014, 2, 12545-12551. [CrossRef]

57. Kshetri, T.; Thanh, T.D.; Singh, S.B.; Kim, N.H.; Lee, J.H. Hierarchical material of carbon nanotubes grown on carbon nanofibers for high performance electrochemical capacitor. Chem. Eng. J. 2018, 345, 39-47. [CrossRef]

58. Kim, T.; Tiwari, A.P.; Chhetri, K.; Ojha, G.P.; Kim, H.; Chae, S.-H.; Dahal, B.; Lee, B.M.; Mukhiya, T.; Kim, H.Y. Phytic acid controlled in situ synthesis of amorphous cobalt phosphate/carbon composite as anode materials with a high mass loading for symmetrical supercapacitor: Amorphization of the electrode to boost the energy density. Nanoscale Adv. 2020, 2, 4918-4929. [CrossRef]

59. Mukhiya, T.; Dahal, B.; Ojha, G.P.; Kang, D.; Kim, T.; Chae, S.-H.; Muthurasu, A.; Kim, H.Y. Engineering nanohaired 3D cobalt hydroxide wheels in electrospun carbon nanofibers for high-performance supercapacitors. Chem. Eng. J. 2019, 361, 1225-1234. [CrossRef]

60. Mukhiya, T.; Tiwari, A.P.; Chhetri, K.; Kim, T.; Dahal, B.; Muthurasu, A.; Kim, H.Y. A metal-organic framework derived cobalt oxide/nitrogen-doped carbon nanotube nanotentacles on electrospun carbon nanofiber for electrochemical energy storage. Chem. Eng. J. 2021, 420, 129679. [CrossRef]

61. Yu, M.; Huang, Y.; Li, C.; Zeng, Y.; Wang, W.; Li, Y.; Fang, P.; Lu, X.; Tong, Y. Building three-dimensional graphene frameworks for energy storage and catalysis. Adv. Funct. Mater. 2015, 25, 324-330. [CrossRef]

62. Dahal, B.; Chhetri, K.; Muthurasu, A.; Mukhiya, T.; Tiwari, A.P.; Gautam, J.; Lee, J.Y.; Chung, D.C.; Kim, H.Y. Biaxial Stretchability in High-Performance, All-Solid-State Supercapacitor with a Double-Layer Anode and a Faradic Cathode Based on Graphitic-2200 Knitted Carbon Fiber. Adv. Energy Mater. 2021, 11, 2002961. [CrossRef]

63. Wang, Y.; Song, Y.; Xia, Y. Electrochemical capacitors: Mechanism, materials, systems, characterization and applications. Chem. Soc. Rev. 2016, 45, 5925-5950. [CrossRef] 
64. Yue, Z.; Dunya, H.; Ashuri, M.; Kucuk, K.; Aryal, S.; Antonov, S.; Alabbad, B.; Segre, C.U.; Mandal, B.K. Synthesis of a very high specific surface area active carbon and its electrical double-layer capacitor properties in organic electrolytes. ChemEngineering 2020, 4, 43. [CrossRef]

65. He, X.; Mao, X.; Zhang, C.; Yang, W.; Zhou, Y.; Yang, Y.; Xu, J. Flexible binder-free hierarchical copper sulfide/carbon cloth hybrid supercapacitor electrodes and the application as negative electrodes in asymmetric supercapacitor. J. Mater. Sci. Mater. Electron. 2020, 31, 2145-2152. [CrossRef]

66. Kang, M.; Zhou, S.; Zhang, J.; Ning, F.; Ma, C.; Qiu, Z. Facile fabrication of oxygen vacancy-rich $\alpha$-Fe2O3 microspheres on carbon cloth as negative electrode for supercapacitors. Electrochim. Acta 2020, 338, 135820. [CrossRef]

67. Chen, L.-F.; Yu, Z.-Y.; Ma, X.; Li, Z.-Y.; Yu, S.-H. In situ hydrothermal growth of ferric oxides on carbon cloth for low-cost and scalable high-energy-density supercapacitors. Nano Energy 2014, 9, 345-354. [CrossRef]

68. Liu, Y.-N.; Zhang, J.-N.; Wang, H.-T.; Kang, X.-H.; Bian, S.-W. Boosting the electrochemical performance of carbon cloth negative electrodes by constructing hierarchically porous nitrogen-doped carbon nanofiber layers for all-solid-state asymmetric supercapacitors. Mater. Chem. Front. 2019, 3, 25-31. [CrossRef]

69. Patiño, J.; López-Salas, N.; Gutiérrez, M.C.; Carriazo, D.; Ferrer, M.L.; del Monte, F. Phosphorus-doped carbon-carbon nanotube hierarchical monoliths as true three-dimensional electrodes in supercapacitor cells. J. Mater. Chem. A 2016, 4, 1251-1263. [CrossRef]

70. Zhang, B.; Kang, F.; Tarascon, J.-M.; Kim, J.-K. Recent advances in electrospun carbon nanofibers and their application in electrochemical energy storage. Prog. Mater. Sci. 2016, 76, 319-380. [CrossRef]

71. Xue, J.; Wu, T.; Dai, Y.; Xia, Y. Electrospinning and Electrospun Nanofibers: Methods, Materials, and Applications. Chem. Rev. 2019, 119, 5298-5415. [CrossRef]

72. Inagaki, M.; Yang, Y.; Kang, F. Carbon Nanofibers Prepared via Electrospinning. Adv. Mater. 2012, 24, 2547-2566. [CrossRef] [PubMed]

73. Joshi, M.K.; Lee, S.; Tiwari, A.P.; Maharjan, B.; Poudel, S.B.; Park, C.H.; Kim, C.S. Integrated design and fabrication strategies for biomechanically and biologically functional PLA/ $\beta$-TCP nanofiber reinforced GelMA scaffold for tissue engineering applications. Int. J. Biol. Macromol. 2020, 164, 976-985. [CrossRef]

74. Tiwari, A.P.; Bhattarai, D.P.; Maharjan, B.; Ko, S.W.; Kim, H.Y.; Park, C.H.; Kim, C.S. Polydopamine-based Implantable Multifunctional Nanocarpet for Highly Efficient Photothermal-chemo Therapy. Sci. Rep. 2019, 9, 2943. [CrossRef]

75. Bhattarai, D.P.; Tiwari, A.P.; Maharjan, B.; Tumurbaatar, B.; Park, C.H.; Kim, C.S. Sacrificial template-based synthetic approach of polypyrrole hollow fibers for photothermal therapy. J. Colloid Interface Sci. 2019, 534, 447-458. [CrossRef]

76. Boys, C.V. On the Production, Properties, and some suggested Uses of the Finest Threads. Proc. Phys. Soc. Lond. 1887, 9, 8-19. [CrossRef]

77. Taylor, G.I. Disintegration of water drops in an electric field. Proc. R. Soc. Lond. Ser. A Math. Phys. Sci. 1964, $280,383-397$. [CrossRef]

78. Taylor, G.I.; Van Dyke, M.D. The force exerted by an electric field on a long cylindrical conductor. Proc. R. Soc. Lond. Ser. A Math. Phys. Sci. 1966, 291, 145-158. [CrossRef]

79. Taylor, G.I.; Van Dyke, M.D. Electrically driven jets. Proc. R. Soc. Lond. A Math. Phys. Sci. 1969, 313, 453-475. [CrossRef]

80. Dai, H.; Gong, J.; Kim, H.; Lee, D. A novel method for preparing ultra-fine alumina-borate oxide fibres via an electrospinning technique. Nanotechnology 2002, 13, 674-677. [CrossRef]

81. Loscertales, I.G.; Barrero, A.; Márquez, M.; Spretz, R.; Velarde-Ortiz, R.; Larsen, G. Electrically Forced Coaxial Nanojets for One-Step Hollow Nanofiber Design. J. Am. Chem. Soc. 2004, 126, 5376-5377. [CrossRef]

82. Li, D.; Wang, Y.; Xia, Y. Electrospinning of Polymeric and Ceramic Nanofibers as Uniaxially Aligned Arrays. Nano Lett. 2003, 3 , 1167-1171. [CrossRef]

83. Li, D.; Xia, Y. Direct Fabrication of Composite and Ceramic Hollow Nanofibers by Electrospinning. Nano Lett. 2004, 4, 933-938. [CrossRef]

84. Sun, Z.; Zussman, E.; Yarin, A.L.; Wendorff, J.H.; Greiner, A. Compound Core-Shell Polymer Nanofibers by Co-Electrospinning. Adv. Mater. 2003, 15, 1929-1932. [CrossRef]

85. Tiwari, A.P.; Joshi, M.K.; Kim, J.I.; Unnithan, A.R.; Lee, J.; Park, C.H.; Kim, C.S. Bimodal fibrous structures for tissue engineering: Fabrication, characterization and in vitro biocompatibility. J. Colloid Interface Sci. 2016, 476, 29-34. [CrossRef] [PubMed]

86. Bhattarai, D.P.; Kim, M.H.; Park, H.; Park, W.H.; Kim, B.S.; Kim, C.S. Coaxially fabricated polylactic acid electrospun nanofibrous scaffold for sequential release of tauroursodeoxycholic acid and bone morphogenic protein 2 to stimulate angiogenesis and bone regeneration. Chem. Eng. J. 2020, 389, 123470. [CrossRef]

87. Liang, J.; Zhao, H.; Yue, L.; Fan, G.; Li, T.; Lu, S.; Chen, G.; Gao, S.; Asiri, A.M.; Sun, X. Recent advances in electrospun nanofibers for supercapacitors. J. Mater. Chem. A 2020, 8, 16747-16789. [CrossRef]

88. Mukhiya, T.; Ojha, G.P.; Dahal, B.; Kim, T.; Chhetri, K.; Lee, M.; Chae, S.-H.; Muthurasu, A.; Tiwari, A.P.; Kim, H.Y. Designed Assembly of Porous Cobalt Oxide/Carbon Nanotentacles on Electrospun Hollow Carbon Nanofibers Network for Supercapacitor. ACS Appl. Energy Mater. 2020, 3, 3435-3444. [CrossRef]

89. Kaerkitcha, N.; Chuangchote, S.; Sagawa, T. Control of physical properties of carbon nanofibers obtained from coaxial electrospinning of PMMA and PAN with adjustable inner/outer nozzle-ends. Nanoscale Res. Lett. 2016, 11, 186. [CrossRef] 
90. El-Deen, A.G.; Barakat, N.A.M.; Khalil, K.A.; Kim, H.Y. Hollow carbon nanofibers as an effective electrode for brackish water desalination using the capacitive deionization process. New J. Chem. 2014, 38, 198-205. [CrossRef]

91. Zhou, Z.; Liu, T.; Khan, A.U.; Liu, G. Block copolymer-based porous carbon fibers. Sci. Adv. 2019, 5, eaau6852. [CrossRef]

92. Wang, C.; Liu, C.; Li, J.; Sun, X.; Shen, J.; Han, W.; Wang, L. Electrospun metal-organic framework derived hierarchical carbon nanofibers with high performance for supercapacitors. Chem. Commun. 2017, 53, 1751-1754. [CrossRef]

93. Li, W.-H.; Ding, K.; Tian, H.-R.; Yao, M.-S.; Nath, B.; Deng, W.-H.; Wang, Y.; Xu, G. Conductive Metal-Organic Framework Nanowire Array Electrodes for High-Performance Solid-State Supercapacitors. Adv. Funct. Mater. 2017, 27, 1702067. [CrossRef]

94. Peng, S.; Li, L.; Kong Yoong Lee, J.; Tian, L.; Srinivasan, M.; Adams, S.; Ramakrishna, S. Electrospun carbon nanofibers and their hybrid composites as advanced materials for energy conversion and storage. Nano Energy 2016, 22, 361-395. [CrossRef]

95. Lai, C.-C.; Lo, C.-T. Preparation of Nanostructural Carbon Nanofibers and Their Electrochemical Performance for Supercapacitors. Electrochim. Acta 2015, 183, 85-93. [CrossRef]

96. Sari, F.N.I.; Ting, J.-M. Direct Growth of MoS2 Nanowalls on Carbon Nanofibers for Use in Supercapacitor. Sci. Rep. 2017, 7, 5999. [CrossRef] [PubMed]

97. Jiang, J.; Li, Y.; Liu, J.; Huang, X.; Yuan, C.; Lou, X.W. Recent Advances in Metal Oxide-based Electrode Architecture Design for Electrochemical Energy Storage. Adv. Mater. 2012, 24, 5166-5180. [CrossRef] [PubMed]

98. Lin, T.; Chen, I.W.; Liu, F.; Yang, C.; Bi, H.; Xu, F.; Huang, F. Nitrogen-doped mesoporous carbon of extraordinary capacitance for electrochemical energy storage. Science 2015, 350, 1508. [CrossRef]

99. Xue, Y.; Ding, Y.; Niu, J.; Xia, Z.; Roy, A.; Chen, H.; Qu, J.; Wang, Z.L.; Dai, L. Rationally designed graphene-nanotube 3D architectures with a seamless nodal junction for efficient energy conversion and storage. Sci. Adv. 2015, 1, e1400198. [CrossRef]

100. Kim, C.; Jeong, Y.I.; Ngoc, B.T.N.; Yang, K.S.; Kojima, M.; Kim, Y.A.; Endo, M.; Lee, J.-W. Synthesis and Characterization of Porous Carbon Nanofibers with Hollow Cores Through the Thermal Treatment of Electrospun Copolymeric Nanofiber Webs. Small 2007, 3, 91-95. [CrossRef]

101. Mukhiya, T.; Dahal, B.; Ojha, G.P.; Chhetri, K.; Lee, M.; Kim, T.; Chae, S.-H.; Tiwari, A.P.; Muthurasu, A.; Kim, H.Y. Silver nanoparticles entrapped cobalt oxide nanohairs/electrospun carbon nanofibers nanocomposite in apt architecture for high performance supercapacitors. Compos. Part B Eng. 2019, 178, 107482. [CrossRef]

102. Wang, H.; Yang, X.; Wu, Q.; Zhang, Q.; Chen, H.; Jing, H.; Wang, J.; Mi, S.-B.; Rogach, A.L.; Niu, C. Encapsulating Silica/Antimony into Porous Electrospun Carbon Nanofibers with Robust Structure Stability for High-Efficiency Lithium Storage. ACS Nano 2018, 12, 3406-3416. [CrossRef] [PubMed]

103. Yan, J.; Dong, K.; Zhang, Y.; Wang, X.; Aboalhassan, A.A.; Yu, J.; Ding, B. Multifunctional flexible membranes from sponge-like porous carbon nanofibers with high conductivity. Nat. Commun. 2019, 10, 5584. [CrossRef]

104. Yang, W.; Zhou, J.; Wang, S.; Zhang, W.; Wang, Z.; Lv, F.; Wang, K.; Sun, Q.; Guo, S. Freestanding film made by necklace-like $\mathrm{N}$-doped hollow carbon with hierarchical pores for high-performance potassium-ion storage. Energy Environ. Sci. 2019, 12, 1605-1612. [CrossRef]

105. Sun, M.-H.; Huang, S.-Z.; Chen, L.-H.; Li, Y.; Yang, X.-Y.; Yuan, Z.-Y.; Su, B.-L. Applications of hierarchically structured porous materials from energy storage and conversion, catalysis, photocatalysis, adsorption, separation, and sensing to biomedicine. Chem. Soc. Rev. 2016, 45, 3479-3563. [CrossRef]

106. Wu, H.B.; Lou, X.W. Metal-organic frameworks and their derived materials for electrochemical energy storage and conversion: Promises and challenges. Sci. Adv. 2017, 3, eaap9252. [CrossRef]

107. Xie, X.-C.; Huang, K.-J.; Wu, X. Metal-organic framework derived hollow materials for electrochemical energy storage. J. Mater. Chem. A 2018, 6, 6754-6771. [CrossRef]

108. Li, Y.; Xu, Y.; Yang, W.; Shen, W.; Xue, H.; Pang, H. MOF-Derived Metal Oxide Composites for Advanced Electrochemical Energy Storage. Small 2018, 14, 1704435. [CrossRef] [PubMed]

109. Arbulu, R.C.; Jiang, Y.-B.; Peterson, E.J.; Qin, Y. Metal-Organic Framework (MOF) Nanorods, Nanotubes, and Nanowires. Angew. Chem. Int. Ed. 2018, 57, 5813-5817. [CrossRef] [PubMed]

110. Li, G.-C.; Liu, P.-F.; Liu, R.; Liu, M.; Tao, K.; Zhu, S.-R.; Wu, M.-K.; Yi, F.-Y.; Han, L. MOF-derived hierarchical double-shelled $\mathrm{NiO} / \mathrm{ZnO}$ hollow spheres for high-performance supercapacitors. Dalton Trans. 2016, 45, 13311-13316. [CrossRef] [PubMed]

111. Yu, C.; Wang, Y.; Cui, J.; Yu, D.; Zhang, X.; Shu, X.; Zhang, J.; Zhang, Y.; Vajtai, R.; Ajayan, P.; et al. MOF-74 derived porous hybrid metal oxide hollow nanowires for high-performance electrochemical energy storage. J. Mater. Chem. A 2018, 6, 8396-8404. [CrossRef]

112. Na, K.; Choi, K.M.; Yaghi, O.M.; Somorjai, G.A. Metal Nanocrystals Embedded in Single Nanocrystals of MOFs Give Unusual Selectivity as Heterogeneous Catalysts. Nano Lett. 2014, 14, 5979-5983. [CrossRef]

113. Xia, W.; Qu, C.; Liang, Z.; Zhao, B.; Dai, S.; Qiu, B.; Jiao, Y.; Zhang, Q.; Huang, X.; Guo, W.; et al. High-Performance Energy Storage and Conversion Materials Derived from a Single Metal-Organic Framework/Graphene Aerogel Composite. Nano Lett. 2017, 17, 2788-2795. [CrossRef]

114. Muthurasu, A.; Chae, S.-H.; Kim, T.; Mukhiya, T.; Kim, H.Y. Template-Assisted Fabrication of ZnO/Co3O4 One-Dimensional Metal-Organic Framework Array Decorated with Amorphous Iron Oxide/Hydroxide Nanoparticles as an Efficient Electrocatalyst for the Oxygen Evolution Reaction. Energy Fuels 2020, 34, 7716-7725. [CrossRef]

115. Tan, Y.; Meng, L.; Wang, Y.; Dong, W.; Kong, L.; Kang, L.; Ran, F. Negative electrode materials of molybdenum nitride/N-doped carbon nano-fiber via electrospinning method for high-performance supercapacitors. Electrochim. Acta 2018, 277, 41-49. [CrossRef] 
116. Yang, Y.; Zhao, L.; Shen, K.; Liu, Y.; Zhao, X.; Wu, Y.; Wang, Y.; Ran, F. Ultra-small vanadium nitride quantum dots embedded in porous carbon as high performance electrode materials for capacitive energy storage. J. Power Sources 2016, 333, 61-71. [CrossRef]

117. Kim, C.; Yang, K. Electrochemical properties of carbon nanofiber web as an electrode for supercapacitor prepared by electrospinning. Appl. Phys. Lett. 2003, 83, 1216-1218. [CrossRef]

118. He, Y.; Wang, L.; Jia, D. Coal/PAN interconnected carbon nanofibers with excellent energy storage performance and electrical conductivity. Electrochim. Acta 2016, 194, 239-245. [CrossRef]

119. Yu, Y.; Gu, L.; Zhu, C.; van Aken, P.A.; Maier, J. Tin Nanoparticles Encapsulated in Porous Multichannel Carbon Microtubes: Preparation by Single-Nozzle Electrospinning and Application as Anode Material for High-Performance Li-Based Batteries. J. Am. Chem. Soc. 2009, 131, 15984-15985. [CrossRef]

120. Fu, B.; Zhou, X.; Wang, Y. Co3O4 carbon nanofiber mats as negative electrodes for sodium-ion batteries. Mater. Lett. 2016, 170, 21-24. [CrossRef]

121. Yao, S.; Guo, R.; Xie, F.; Wu, Z.; Gao, K.; Zhang, C.; Shen, X.; Li, T.; Qin, S. Electrospun three-dimensional cobalt decorated nitrogen doped carbon nanofibers network as freestanding electrode for lithium/sulfur batteries. Electrochim. Acta 2020, 337, 135765. [CrossRef]

122. Lu, F.; Wang, J.; Sun, X.; Chang, Z.3D hierarchical carbon nanofibers/TiO2@MoS2 core-shell heterostructures by electrospinning, hydrothermal and in-situ growth for flexible electrode materials. Mater. Des. 2020, 189, 108503. [CrossRef]

123. Heo, Y.-J.; Park, M.; Kang, W.-S.; Rhee, K.Y.; Park, S.-J. Preparation and characterization of carbon black/pitch-based carbon fiber paper composites for gas diffusion layers. Compos. Part B Eng. 2019, 159, 362-368. [CrossRef]

124. Zhang, M.Y.; Niu, H.Q.; Qi, S.L.; Tian, G.F.; Wang, X.D.; Wu, D.Z. Structure evolutions involved in the carbonization of polyimide fibers with different chemical constitution. Mater. Today Commun. 2014, 1, 1-8. [CrossRef]

125. Kuzmenko, V.; Wang, N.; Haque, M.; Naboka, O.; Flygare, M.; Svensson, K.; Gatenholm, P.; Liu, J.; Enoksson, P. Cellulose-derived carbon nanofibers/graphene composite electrodes for powerful compact supercapacitors. RSC Adv. 2017, 7, 45968-45977. [CrossRef]

126. Zhang, L.; Xia, G.; Guo, Z.; Sun, D.; Li, X.; Yu, X. In situ fabrication of three-dimensional nitrogen and boron co-doped porous carbon nanofibers for high performance lithium-ion batteries. J. Power Sources 2016, 324, 294-301. [CrossRef]

127. Wei, J.; Geng, S.; Pitkänen, O.; Järvinen, T.; Kordas, K.; Oksman, K. Green Carbon Nanofiber Networks for Advanced Energy Storage. ACS Appl. Energy Mater. 2020, 3, 3530-3540. [CrossRef]

128. Heo, Y.-J.; Zhang, Y.; Rhee, K.Y.; Park, S.-J. Synthesis of PAN/PVDF nanofiber composites-based carbon adsorbents for CO2 capture. Compos. Part B Eng. 2019, 156, 95-99. [CrossRef]

129. Yang, J.; Wang, Y.; Luo, J.; Chen, L. Highly nitrogen-doped graphitic carbon fibers from sustainable plant protein for supercapacitor. Ind. Crops Prod. 2018, 121, 226-235. [CrossRef]

130. Lu, J.; Wan, H.; Ju, T.; Ying, Z.; Zhang, W.; Li, B.; Zhang, Y. Super flexible electrospun carbon/nickel nanofibrous film electrode for supercapacitors. J. Alloys Compd. 2019, 774, 593-600. [CrossRef]

131. Tian, D.; Lu, X.; Nie, G.; Gao, M.; Wang, C. Direct growth of Ni-Mn-O nanosheets on flexible electrospun carbon nanofibers for high performance supercapacitor applications. Inorg. Chem. Front. 2018, 5, 635-642. [CrossRef]

132. Tian, S.; Jiang, Q.; Cai, T.; Wang, Y.; Wang, D.; Kong, D.; Ren, H.; Zhou, J.; Xing, W. Graphitized electrospun carbon fibers with superior cyclability as a free-standing anode of potassium-ion batteries. J. Power Sources 2020, 474, 228479. [CrossRef]

133. Kim, S.E.; Tiwari, A.P. Three dimensional polycaprolactone/cellulose scaffold containing calcium-based particles: A new platform for bone regeneration. Carbohydr. Polym. 2020, 250, 116880. [CrossRef] [PubMed]

134. Tang, Z.; Zhang, G.; Zhang, H.; Wang, L.; Shi, H.; Wei, D.; Duan, H. MOF-derived N-doped carbon bubbles on carbon tube arrays for flexible high-rate supercapacitors. Energy Storage Mater. 2018, 10, 75-84. [CrossRef]

135. Cao, X.-M.; Sun, Z.-J.; Zhao, S.-Y.; Wang, B.; Han, Z.-B. MOF-derived sponge-like hierarchical porous carbon for flexible all-solid-state supercapacitors. Mater. Chem. Front. 2018, 2, 1692-1699. [CrossRef] 